\title{
Specific Gravity Analysis of Onion Peel and Snail Shell Particulates as Composite Fillers in Ship Applications
}

\author{
Sunday Ayoola Oke ${ }^{1}$ \\ (Received: 23 January 2021 / Revised: 25 January 2021 / Accepted: 23 February 2021)
}

\begin{abstract}
— there is limited knowledge on the specific gravity of agro-based fillers, particularly particulate onion peels and snail shells despite their potentials as the ship's hull composite materials. This work reports experimental results on specific gravity concerning particulate onion peels and snail shells as fillers in ship's hull composite fabrication. Specific gravity bottles, water, and 15g each of particulate onion peels, snail shells, and their mixtures were used in laboratory conditions. It was found that onion peel particulates (specific gravity of $1.09 \pm 0.41$ for $0.063 \mathrm{~mm}$ ), snail shell particulates (specific gravity of $0.95 \pm 0.01$ for $0.063 \mathrm{~mm}$ ), and mixtures of particulate onion peel and snail shell (specific gravity of $1.02 \pm 0.08$ for 0.150 $\mathrm{mm}, 10 \mathrm{~g}$ particulate onion peels $+5 \mathrm{~g}$ particulate snail shell) yielded the least values, requiring the least fuel expenditure in generating torque for the desired motions during the ship's voyage. Moreover, a policy to use the snail shell recommendation should be formulated as it is the overall best to help in cost reduction by shipping organizations. Previous studies were on tomatoes and potatoes, among others. However, the present study takes a new direction to innovatively consider hardly studied fillers for polymer composites for the first time.
\end{abstract}

Keywords-experiments, physical measurements, properties, water.

\section{INTRODUCTION}

The physical characteristics study of specific gravity regarding agro-based reinforcements is concerned with experimental details to analyze the reinforcement particulates when suspended in water with the differences between the suspended weights in water and dry weights evaluated as the specific gravity $[1,2,3]$. This analysis promotes the suitability of a grade of material over the other. For instance, the $0.053 \mathrm{~mm}$ microscale grade of onion peels may have better (lower) specific gravity than the $0.063 \mathrm{~mm}$ grade. The analysis may also prefer a type of material to the other. For instance, mixed onion peel and snail shell particulates of $5 \mathrm{~g}$ each, with $0.053 \mathrm{~mm}$ micro-grade may be preferred to any other grade of either onion peel particulates alone or snail shell particular alone. In a specific gravity study, the lower values of the measured outcome are chosen as the preferred reinforcement particulates in the tests.

However, the need for specific gravity study may be noted in the previous studies, including Wiemann and Williamson [2], Van Niekerk et al. [3], Tessema et al. [4], and Jahanbakhshi et al. [5]. Interestingly, the use of acceptable grades of specific gravity values has been associated with interactions and improvements of the mechanical properties of the materials. Accordingly, researchers have revealed information on the specific gravity of materials. An early study to establish a method of specific gravity dates back to 1945 when Byers [6] estimated the specific gravity of veneer. The research voyage was to determine light and brittle materials as exclusion materials for aircraft building. This research navigation brought the discovery to include the specific gravity of mahogany, yellow poplar, and birch.

Sunday Ayoola Oke is with the Department of Mechanical Engineering, University of Lagos, 100213, Nigeria. E-mail: sa_oke@yahoo.com
Years of research silence or scanty documentation were ensured after Byers' effort. In 1962, Sung and Delouche [7] established the association between the specific gravity of rice and seedling vigor. The study took a global perspective to review relevant particles on rice and agricultural seeds in general according to specific gravity. These included activities in Japan, Taiwan, Europe, and North America. Laberge [8] established the specific gravity of malt extracts, beer, and worts and pronounced excellent correlations of this attribute among the alternative considered. SicilianoJones and Murphy [9] established the specific gravity of various feedstuffs and their association with a particle size as well as in vitro fermentation. Wright et al. [10] analyzed the influences of specific gravity as well as cultivar on potato tubers' likehoods of having bacterial.

Ndukwu [1] studied the specific (solid) density of Brachystegia Eurycoma and related the outcome with the design features of the handling equipment. Specific gravity was declared to exhibit the greatest and least deviation of $4.04 \mathrm{~g} / \mathrm{mm}^{3}$ and $0.01 \mathrm{~mm}^{3}$, respectively when weighed against other physical characteristics of the material. Wiemann and Williamson [2] elaborated on the specific gravity of biomass with discussions on the influence of wood decline and reliance on established indices regarding specific density. Van Niekerk et al. [3] established the reliability of the specific gravity of potato tuber. It was reported that the specific gravity method used excludes standardization and brings doubts to its reliability among other methods. Melito et al. [11] analyzed the specific gravity in potatoes. Variations in specific gravity were noticed in the families and clones of the potato selections. Roughly $30 \%$ of clones revealed a superior specific gravity (>1.080). Jahanbakhshi et al. [5] analyzed the specific density of tomatoes in transportation in water, during transportation, and separation activities. Tessema et al. [4] measured the 
specific gravity of potatoes and analyzed some of the potato's agronomic traits.

In this study, the problem statement argues that there is a paucity of studies to indicate the specific gravity of onion peel particulates, snail shell particulates or a combination of onion peels and snail shell particulates with lower values for the least torque requirement to propel the ship. The ship's hull may be fabricated with the selected material and the torque needed for propulsion will be less when compared with the proportion torque requirement to drive the shipping vessel when made with metals. To resolve this research and practice challenge, the present study instigated an inquiry on the specific gravity particulate onion peels snail shell and combined onion peels and snail shells. In this research, the authors determined to study the specific gravity concern of two agro-wastes with threatening environmental concerns as wastes deposited indiscriminately in the environment.

The global trend for waste control and its conversion into useful products is well-discussed in the literature. A striking example is a proclamation by Jahanbakhshi et al. [5] to control waste, which was declared as constituting above $30 \%$ of agricultural products at various phases from products harvesting to consumption. The value may be a good indication of the threshold of waste in many countries of the world, including Nigeria whose wastes are converted into reinforcements to composites in this work. These wastes may be converted to ship's hull members in composite forms for economic gains in converting wastes to wealth and ship's energy efficiency improvement by reducing the fuel consumption of the ship during operation. This area of advancements in composites research came about for some motives. The global economy has placed severe pressure on ship vessel management to learn practices of reducing cost and promoting performance excellence.

The study by Alshawi and Avtandi [12] revealed that enhanced voyage planning through an optimum route and enhanced efficiency is compelling for ship vessels this is guided by the IMD resolution A.893(21)(25 November 1999) that direct voyage planners and crew of vessels on the attainment of the aforementioned goal [12, 13] agreed that route planning optimization could yield substantial fuel savings. Consequently, it was conceived that substitutes of the present metallic/aluminum or some alloys make of ship's hull with particulate of onion peels, snail shell or their combined forms promotes great fuel efficiency. It is thought that the torque required using composites reinforced with the mentioned materials would be less and then less fuel consumption will be experienced. Alshawi and Alvtandil [12] insisted that voyage conditions have influenced the resistance experienced by the shipping vessel from water and it is thought that reducing the ship's hull load against the resistance of the ship from water would help the fuel efficiency goal of the shipping management.

Consequently, as a result of the evidence emerging from the literature, a broad scope of research prospects exists for onion peels, snail shell, and their combined forms as reinforced forms of reinforcements to polymer composites. Hence, through experiments, these reinforcements will be analyzed and this would be achieved using the specific gravity bottles, tap water, agro-waste collected from retailers in markets, and the use of machines.

\section{METHOD}

The specific gravity has a great significance for energy resource allocation decisions regarding ship's hull composite structures in water environments. High specific gravity composite reinforcements have a poor influence on propulsion as higher torques are needed to achieve desired motion intentions. This makes the applications of high specific gravity reinforcements in composites difficult and expensive. The specific gravity was established by weighing a pre-determined weight of reinforcement in the air (dry weight) and consequently in water, as reflected in Gould [14] and Tessema et al. [4]. The principal target of our experiment is to achieve the least measured specific gravity measured values of the OPPs, SSPs, and the mixed OPPS and SSPs. The expression of the specific gravity which considers the weights of the samples dried and when mixed with water is used for the computation. The formula for specific gravity is given as follows:

Specific gravity $=$ Weight of reinforcements / $/$ weight of reinforcements in air - weight of reinforcement in the air)

For the evaluation of the mixed OPPS and SSPs, numerous researchers have attempted to appraise the physical properties of OPPs and SSPs independently to obtain characteristics to use for further studies. Unfortunately, to date, no mixed compositions of OPPs and SSPs have been established to obtain the specific gravity of the mixture in a water solution of the samples. Presently, this has is an urgent requirement for study.

\section{RESULTS AND DISCUSSION}

The following grades of particulates were obtained for the sieved samples using the automatic segregation component: $0.053,0.063,0.150,0.180,0.300,0.425$, and $0.600 \mathrm{~mm}$ (Table 1 to Table 6). Of these seven grades, the first two grades 0.053 and $0.063 \mathrm{~mm}$ are unlike others are they tending towards the nanoscale. Sieving experience recalls that some particles that pass through the last grade, $0.053 \mathrm{~mm}$, and were tested for particle size have successfully been confirmed as nanoparticles. It is clear from the articles reviewed in the literature section that substantial importance has been attached to the role that specific gravity plays in influencing the physical characteristics of agro-based fillers and this will be useful in the development of a ship's hull for structural applications. 
TABLE 1

15G (OPPS) FOR SAMPLE SIZES $0.053 \mathrm{MM}$ TO $0.425 \mathrm{MM}$

\begin{tabular}{|c|c|c|c|c|c|c|}
\hline Bottle label & $\begin{array}{c}0.053 \mathrm{~mm} \\
(\mathrm{~A}+\mathrm{B}+\mathrm{C}) \mathrm{g} \\
\end{array}$ & $\begin{array}{c}0.063 \mathrm{~mm}^{*} \\
(\mathrm{~A}+\mathrm{B}+\mathrm{C}) \mathrm{g}\end{array}$ & $\begin{array}{c}0.150 \mathrm{~mm} \\
(\mathrm{~A}+\mathrm{B}+\mathrm{C}) \mathrm{g}\end{array}$ & $\begin{array}{c}0.212 \mathrm{~mm} \\
(\mathrm{~A}+\mathrm{B}+\mathrm{C}) \mathrm{g}\end{array}$ & $\begin{array}{c}0.300 \mathrm{~mm} \\
(\mathrm{~A}+\mathrm{B}+\mathrm{C}) \mathrm{g}\end{array}$ & $\begin{array}{c}0.425 \mathrm{~mm} \\
(\mathrm{~A}+\mathrm{B}+\mathrm{C}) \mathrm{g}\end{array}$ \\
\hline Wt of bottle + stopper $\left(\mathrm{w}_{1}\right)$ & 81.35 & 81.35 & 81.35 & 81.35 & 81.35 & 81.35 \\
\hline Wt of bottle + stopper + sample $\left(\mathrm{w}_{2}\right)$ & 96.35 & 96.35 & 96.35 & 96.35 & 96.35 & 96.35 \\
\hline Wt of bottle + stopper + sample + water $\left(\mathrm{w}_{3}\right)$ & 238.26 & 233.33 & 238.48 & 238.26 & 237.47 & 237.68 \\
\hline Wt of bottle + stopper + sample + water $\left(\mathrm{w}_{4}\right)$ & 233.34 & 233.34 & 233.34 & 233.34 & 233.34 & 233.34 \\
\hline Gs & $1.49 \pm 0.08$ & $1.09 \pm 0.41$ & $1.52 \pm 0.02$ & $1.49 \pm 0.06$ & $1.37 \pm 0.05$ & $1.41 \pm 0.03$ \\
\hline
\end{tabular}

*best alternative

TABLE 2.

15G (SSPS) FOR SAMPLE SIZES 0.053 MM TO 0.600 MM

\begin{tabular}{|c|c|c|c|c|c|c|c|}
\hline Bottle label & $\begin{array}{l}0.053 \mathrm{~mm}^{*} \\
(\mathrm{~A}+\mathrm{B}+\mathrm{C}) \mathrm{g}\end{array}$ & $\begin{array}{l}0.063 \mathrm{~mm}^{*} \\
(\mathrm{~A}+\mathrm{B}+\mathrm{C}) \mathrm{g}\end{array}$ & $\begin{array}{c}0.075 \mathrm{~mm} \\
(\mathrm{~A}+\mathrm{B}+\mathrm{C}) \mathrm{g}\end{array}$ & $\begin{array}{c}\mathbf{0 . 1 5 0} \mathrm{mm} \\
(\mathrm{A}+\mathrm{B}+\mathrm{C}) \mathrm{g}\end{array}$ & $\begin{array}{c}0.212 \mathrm{~mm} \\
(\mathrm{~A}+\mathrm{B}+\mathrm{C}) \mathrm{g}\end{array}$ & $\begin{array}{c}0.300 \mathrm{~mm} \\
(\mathrm{~A}+\mathrm{B}+\mathrm{C}) \mathrm{g}\end{array}$ & $\begin{array}{c}0.600 \mathrm{~mm} \\
(\mathrm{~A}+\mathrm{B}+\mathrm{C}) \mathrm{g}\end{array}$ \\
\hline Wt of bottle + stopper $\left(\mathrm{w}_{1}\right)$ & 81.35 & 81.35 & 81.35 & 81.35 & 81.35 & 81.35 & 81.35 \\
\hline Wt of bottle + stopper + sample $\left(\mathrm{w}_{2}\right)$ & 96.35 & 96.35 & 96.35 & 96.35 & 96.35 & 96.35 & 96.35 \\
\hline Wt of bottle + stopper + sample + water $\left(\mathrm{w}_{3}\right)$ & 232.57 & 233.55 & 233.98 & 235.53 & 234.38 & 235.18 & 233.90 \\
\hline Wt of bottle + stopper + sample + water $\left(\mathrm{w}_{4}\right)$ & 233.34 & 233.34 & 233.34 & 233.34 & 233.34 & 233.34 & 233.34 \\
\hline Gs & $0.95 \pm 0.03$ & $0.95 \pm 0.01$ & $1.05 \pm 0.10$ & $1.18 \pm 0.12$ & $1.08 \pm 0.06$ & $1.04 \pm 0.05$ & $1.17 \pm 0.02$ \\
\hline
\end{tabular}

*best alternative

TABLE 3.

MIXTURES OF 5G (OPPS) + 5G (SSPS) FOR SAMPLE SIZES 0.053 MM TO $0.425 \mathrm{MM}$

\begin{tabular}{|c|c|c|c|c|c|c|}
\hline Bottle label & 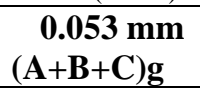 & $\begin{array}{c}0.063 \mathrm{~mm}^{*} \\
(\mathrm{~A}+\mathrm{B}+\mathrm{C}) \mathrm{g}\end{array}$ & $\begin{array}{c}\mathbf{0 . 1 5 0} \mathbf{~ m m} \\
(\mathrm{A}+\mathrm{B}+\mathrm{C}) \mathrm{g}\end{array}$ & $\begin{array}{c}0.212 \mathrm{~mm} \\
(\mathrm{~A}+\mathrm{B}+\mathrm{C}) \mathrm{g}\end{array}$ & $\begin{array}{c}\mathbf{0 . 3 0 0 ~ m m} \\
(\mathrm{A}+\mathrm{B}+\mathrm{C}) \mathrm{g}\end{array}$ & $\begin{array}{c}0.425 \mathrm{~mm} \\
(\mathrm{~A}+\mathrm{B}+\mathrm{C}) \mathrm{g}\end{array}$ \\
\hline Wt of bottle + stopper $\left(\mathrm{w}_{1}\right)$ & 81.35 & 81.35 & 81.35 & 81.35 & 81.35 & 81.35 \\
\hline Wt of bottle + stopper + sample $\left(\mathrm{w}_{2}\right)$ & 111.35 & 111.35 & 111.35 & 111.35 & 111.35 & 111.35 \\
\hline Wt of bottle + stopper + sample + water $\left(\mathrm{w}_{3}\right)$ & 233.91 & 233.91 & 239.39 & 241.84 & 240.94 & 240.96 \\
\hline Wt of bottle + stopper + sample + water $\left(\mathrm{w}_{4}\right)$ & 233.34 & 233.34 & 233.34 & 233.34 & 233.34 & 233.34 \\
\hline Gs & $1.20 \pm 0.11$ & $1.04 \pm 0.21$ & $1.25 \pm 0.04$ & $1.39 \pm 0.02$ & $1.34 \pm 0.03$ & $1.34 \pm 0.05$ \\
\hline
\end{tabular}

*best alternative 
TABLE 4

MIXTURES OF 5G (OPPS) +10G (SSPS) FOR SAMPLE SIZES 0.053 MM TO $0.425 \mathrm{MM}$

\begin{tabular}{|c|c|c|c|c|c|c|}
\hline Bottle label & $\begin{array}{c}0.053 \mathrm{~mm} \\
(\mathrm{~A}+\mathrm{B}+\mathrm{C}) \mathrm{g} \\
\end{array}$ & $\begin{array}{c}0.063 \mathrm{~mm}^{*} \\
(\mathrm{~A}+\mathrm{B}+\mathrm{C}) \mathrm{g}\end{array}$ & $\begin{array}{c}0.150 \mathrm{~mm} \\
(\mathrm{~A}+\mathrm{B}+\mathrm{C}) \mathrm{g}\end{array}$ & $\begin{array}{c}0.212 \mathrm{~mm} \\
(\mathrm{~A}+\mathrm{B}+\mathrm{C}) \mathrm{g}\end{array}$ & $\begin{array}{c}0.300 \mathrm{~mm} \\
(\mathrm{~A}+\mathrm{B}+\mathrm{C}) \mathrm{g} \\
\end{array}$ & $\begin{array}{c}0.425 \mathrm{~mm} \\
(\mathrm{~A}+\mathrm{B}+\mathrm{C}) \mathrm{g}\end{array}$ \\
\hline Wt of bottle + stopper $\left(\mathrm{w}_{1}\right)$ & 81.35 & 81.35 & 81.35 & 81.35 & 81.35 & 81.35 \\
\hline Wt of bottle + stopper + sample $\left(\mathrm{w}_{2}\right)$ & 126.35 & 126.35 & 126.35 & 126.35 & 126.35 & 126.35 \\
\hline Wt of bottle + stopper + sample + water $\left(\mathrm{w}_{3}\right)$ & 237.94 & 236.82 & 243.01 & 244.97 & 245.98 & 244.29 \\
\hline Wt of bottle + stopper + sample + water $\left(\mathrm{w}_{4}\right)$ & 233.34 & 233.34 & 233.34 & 233.34 & 233.34 & 233.34 \\
\hline Gs & $1.13 \pm 0.14$ & $1.09 \pm 0.05$ & $1.28 \pm 0.07$ & $1.35 \pm 0.08$ & $1.39 \pm 0.02$ & $1.33 \pm 0.07$ \\
\hline
\end{tabular}

*best alternative

TABLE 5

MIXTURES OF 10G (OPPS) +5G (SSPS) FOR SAMPLE SIZES 0.053 MM TO $0.425 \mathrm{MM}$

\begin{tabular}{|c|c|c|c|c|c|c|}
\hline Bottle label & $\begin{array}{c}\mathbf{0 . 0 5 3} \mathbf{~ m m} \\
(\mathrm{A}+\mathrm{B}+\mathrm{C}) \mathrm{g}\end{array}$ & $\begin{array}{c}\mathbf{0 . 0 6 3 ~ m m} \\
(\mathrm{A}+\mathrm{B}+\mathrm{C}) \mathrm{g}\end{array}$ & $\begin{array}{l}\mathbf{0 . 1 5 0} \mathrm{mm}^{*} \\
(\mathrm{~A}+\mathrm{B}+\mathrm{C}) \mathrm{g}\end{array}$ & $\begin{array}{c}0.212 \mathrm{~mm} \\
(\mathrm{~A}+\mathrm{B}+\mathrm{C}) \mathrm{g}\end{array}$ & $\begin{array}{c}\mathbf{0 . 3 0 0 ~ m m} \\
(\mathrm{A}+\mathrm{B}+\mathrm{C}) \mathrm{g}\end{array}$ & $\begin{array}{c}0.425 \mathrm{~mm} \\
(\mathrm{~A}+\mathrm{B}+\mathrm{C}) \mathrm{g}\end{array}$ \\
\hline Wt of bottle + stopper $\left(\mathrm{w}_{1}\right)$ & 81.35 & 81.35 & 81.35 & 81.35 & 81.35 & 81.35 \\
\hline Wt of bottle + stopper + sample $\left(\mathrm{w}_{2}\right)$ & 126.35 & 126.35 & 126.35 & 126.35 & 126.35 & 126.35 \\
\hline Wt of bottle + stopper + sample + water $\left(\mathrm{w}_{3}\right)$ & 241.28 & 237.94 & 234.44 & 236.58 & 240.50 & 239.00 \\
\hline Wt of bottle + stopper + sample + water $\left(\mathrm{w}_{4}\right)$ & 233.34 & 233.34 & 233.34 & 233.34 & 233.34 & 233.34 \\
\hline 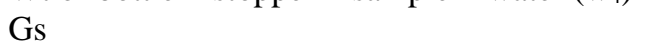 & $1.22 \pm 0.04$ & $1.12 \pm 0.04$ & $1.03 \pm 0.08$ & $1.08 \pm 0.03$ & $1.19 \pm 0.03$ & $1.14 \pm 0.04$ \\
\hline
\end{tabular}

*best alternative

TABLE 6

WEIGHTS OF VARIOUS GRADES SIEVED OUT OF OPPS AND SSPS

\begin{tabular}{|c|c|c|c|c|}
\hline Sieve size $(\mathrm{mm})$ & $\begin{array}{l}\text { Weight of onion peel } \\
\text { particles (g) }\end{array}$ & $\%$ of the total weight & $\begin{array}{c}\text { Weight of snail shell } \\
\text { particles (g) }\end{array}$ & $\%$ of the total weight \\
\hline 1.18 & 0.17 & 0.03 & 15.58 & 0.22 \\
\hline 0.600 & 2.46 & 0.43 & 126.73 & 1.75 \\
\hline 0.425 & 82.63 & 14.56 & 462.98 & 6.40 \\
\hline 0.300 & 134.70 & 23.74 & 911.73 & 12.60 \\
\hline 0.212 & 121.62 & 21.44 & 1068.44 & 14.77 \\
\hline 0.150 & 74.93 & 13.21 & 1026.89 & 14.20 \\
\hline 0.075 & - & 0 & 1836.14 & 25.38 \\
\hline 0.063 & 82.10 & 14.47 & 1028.22 & 14.21 \\
\hline 0.053 & 68.77 & 12.12 & 756.77 & 10.46 \\
\hline
\end{tabular}


The OPPs and SSPs and their mixtures are expected to produce structures that will require the least torque in obtaining the desired output from the ship's hull. By keeping the above issues in mind, the specific gravity of OPPs, SPPs, and the mixture of OPPs and SSPs have been experimentally analyzed to evaluate the various responses for several grades of the particulates ranging from 0.053 to $0.425 \mathrm{~mm}$. The specific gravity experiment was conducted at room temperature and pressure using the specific density bottles. The most fascinating findings of this research are noted in the multiple manners in which the specific gravity of the samples is revealed. A broad scope of particulate sizes from 0.053 to $0.600 \mathrm{~mm}$ for each of the OPPs, SSPs, and mixtures of these particulates provided an opportunity to understand the specific gravity of the agro-based fillers. The most attractive findings were the $1.09 \pm 1.05$ value yielded by the $0.063 \mathrm{~mm}$ grade of the mixture regarding $5 \mathrm{~g}$ of OPPs and $10 \mathrm{~g}$ of SSPs.

The research sought to explore the best recommended specific gravity for practical application to develop the ship's hull. It is through that adopting the stated grade of OPPs and SSPs mixtures would reduce the required torques generated to propel the ship. To sharpen our understanding of the performance of the filler for water applications and enhance its integrity, binders are strongly suggested for use in composite fabrication.

\section{CONCLUSIONS}

The OPPs, SSPs, and mixed forms have been experimented upon regarding their specific gravity to determine the honest values of the diverse particle sizes and weight that yield the best values. the following conclusion was arrived at:

1. It is feasible to analyze the specific gravity of OPPS, SSPs, and mixed OPPs and SSPs relative to water mixtures.

2. For the mixture of $5 \mathrm{~g}(\mathrm{OPPs})$ and $10 \mathrm{~g}$ (SSPs) for sample sizes $0.053 \mathrm{~min}$ to $0.425 \mathrm{~mm}$, the least specific gravity is $1.09 \pm 0.05$, obtained at $0.063 \mathrm{~mm}$

3. Concerning the mixture of $10 \mathrm{~g}(\mathrm{OPPs})$ and $5 \mathrm{~g}$ (SSPs) for sample sizes $0.053 \mathrm{~mm}$ to 0.425 $\mathrm{mm}$, the lowest specific gravity is $1.03 \pm 0.08$, attained at $0.150 \mathrm{~mm}$.

4. for the mixture of $5 \mathrm{~g}$ (OPPS) and $5 \mathrm{~g}$ (SSPS) for sample sizes $0.053 \mathrm{~mm}$ to $0.425 \mathrm{~mm}$, the least specific gravity is $1.04 \pm 0.21$, achieved at 0.63 $\mathrm{mm}$

5. Regarding the $15 \mathrm{~g}$ (SSPs) for sample sizes $0.053 \mathrm{~mm}$ to $0.600 \mathrm{~mm}$, the lowest specific gravity is a tie between $0.95 \pm 0.03$ and $0.95 \pm 0.01$ for 0.053 and $0.063 \mathrm{~mm}$, respectively.

6. For the $15 \mathrm{~g}$ (OPPs) for sample size $0.053 \mathrm{~mm}$ to $0.425 \mathrm{~mm}$, the lowest specific gravity was obtained as $1.09 \pm 0.41 \mathrm{~mm}$ at $0.063 \mathrm{~mm}$ sieve grade of particles.

7. During sieving of OPPs the $0.053 \mathrm{~mm}$, which tends toward nanoparticle was obtained at $12.12 \%$ of the volume of particle sieved. However, for the SSPs, the percentage obtained for the $0.053 \mathrm{~mm}$ is $10.46 \%$

\section{REFERENCES}

[1] M.C. Ndukwu. Determination of selected physical properties of Brachystegia eurycoma seeds, Research in Agricultural Engineering, vol. 55, no. 4, pp. 165-169, 2009.

[2] M.C. Wiemann, G.B. Williamson 2012. Density and specific gravity metrics in biomass research. General Technical Report FPL-GTR-208. Madison, WI: U.S. Department of Agriculture, Forest Service, Forest Products Laboratory. 6 p.

[3] C. Van Niekerk, H.C. Schönfeldt, N. Hall and B. Pretorius. The reliability of dry matter, specific gravity, starch, and glycaemic index to classify potatoes, International Journal of Agriculture and Environmental Research, vol. 2, no. 5, pp. 1420-1427, 2016.

[4] L. Tessema, W. Mohammed and T. Abebe. Evaluation of potato (Solanum tuberosum L.) varieties for yield and some agronomic traits, Open Agriculture, vol. 5, no. 1, 2020. https://doi.org/10.1515/opag-2020-0006

[5] A. Jahanbakhshi, V.R. Sharabiani, K. Heidarbeigi, M. Kaveh, and E. Taghinezhad. Evaluation of engineering properties for waste control of tomato during harvesting and postharvesting, Food Science and Nutrition, vol. 7, no. 4, pp. 1473-1481, 2019. doi: $10.1002 /$ fsn 3.986

[6] T.K. Byers. A simple method of determining the specific gravity of veneer, Journal of Forestry, vol. 43, no. 8, pp. 599-600, 1945. https://doi.org/10.1093/jof/43.8.599

[7] T.Y. Sung and J.C. Delouche. Relation of specific gravity to vigor and viability in rice seed, Proceedings of the Association of Official Seed Analysts, vol. 52, pp. 162-168, 1962.

[8] D. E. LaBerge. Determination of specific gravity of malt extracts, worts, and beer, Journal of the American Society of Brewing Chemists: The Science of Beer, vol. 37, no. 2, pp. 105-106. 1979. https://doi.org/10.1094/ASBCJ-37-0105

[9] J. Siciliano-Jones, M.R. Murphy. Specific gravity of various feedstuffs as affected by particle size and in vitro fermentation, Journal of Dairy Science, vol. 74, no. 3, pp. 896-901, 1991.

[10] P.J. Wright, C.M. Triggs \& J.A.D. Anderson. Effects of specific gravity and cultivar on susceptibility of potato (Solanum tuberosum) tubers to blackspot bruising and bacterial soft rot, New Zealand Journal of Crop and Horticultural Science, vol. 33, no. 4, pp. 353-361. 2005. https://doi.org/10.1080/01140671.2005.9514370

[11] S. Melito, R. Garramone, C. Villano \& D. Carputo. Chipping ability, specific gravity and resistance to Pectobacterium carotovorum in advanced potato selections, New Zealand Journal of Crop and Horticultural Science, vol. 45, no. 2, pp. 81-90. 2017. https://doi.org/10.1080/01140671.2016.1256327

[12] OSMA Alshawi and T. Avtandi, Ship energy efficiency management plan: Analysis of biofouling effect on $\mathrm{CO}_{2}$ emission performance of Iraq non-trading fleet (2019). World Maritime University Dissertations. 1186. https://commons.wmu.se/all_dissertations/1186

[13] R. Baumler, M. Baldauf, A. Ölçer, T. Nakazawa, K. Benedict, S. Fischer, \& M. Schaub (2013, June). Energy-efficient ship operation - training requirements and challenges. vol. 7 , no. 2 June 2013. Retrieved August 19, 2019, from Imo.org Web site:

http://www.imo.org/en/OurWork/Environment/PollutionPrevention/Ai rPollution/Documents/Technical\%20cooperation/Energy\%20Effic ient\%20Operation.pdf

[14] W. Gould 1995. Specific gravity-its measurement and use. Chipping Potato Handbook 